\title{
The Needs of Families with Mentally Disabled Teenagers for Sexual Education Process
}

\author{
Ayşe Bengisoy (Corresponding author) \\ Dept. of Guidance and Psychological Counseling, Cyprus International University \\ Lefkosa, Cyprus
}

Tel: 9-392-671-1111 E-mail: bengisoyayse@gmail.com

Gürcan Seçim

Dept. of Guidance and Psychological Counseling, Cyprus International University

Lefkosa, Cyprus

Tel: 9-392-671-1111 E-mail: gozhan@ciu.edu.tr

Doi:10.5296/ijld.v4i4.6259 URL: http://dx.doi.org/10.5296/ijld.v4i4.6259

\begin{abstract}
This research concerns itself with the needs and requirements of parents with teenagers between the ages of 13-18, who have been diagnosed as mentally disabled and are being educated in a special Ministry of Education facility in Northern Cyprus, in regards to their experiences with the sexual education procedure. There are currently 20 students in the facility, with their ages ranging between 13 and 18. In order to gather suitable data, a qualitative approach involving interviews has been pursued, and a semi-structured interview method was put in use. In the analysis of the data gathered, a descriptive analytic method as on par with the qualitative techniques that are used has been the primary method for analysis. The research concluded with the analysis of interview findings and expose the needs and requirements of families for sexual education process with mentally disabled children in terms of behavioral and social dimensions.
\end{abstract}

Keywords: needs, family, mental deficiency, sexual education, special education, work group.

\section{Introduction}

Whether an individual of special needs or not, the approach of the family regarding the sexual development process and education thereof holds special importance for sexual education and the sexual development process to be healthy. If we consider our biological nature, we are designated a sex which is either male or female. Sexuality is a concept that encompasses the addition of sociological, psychological, and philosophical concepts on top of the existing biological basis. It is a process that starts before birth, and includes all the emotions, feelings, beliefs, thoughts, actions and experiences until death. The sexual feelings, emotions, beliefs and actions that are expected in a certain point in life, shape the appropriate sexual development for that age(Mc Cabe, 1999).

Sexual education is a phenomenon that begins at birth and continues throughout the life of a individual. With sexual education, an individual is able to make sense of one's own sexual development process, to generate positive behavior and attitude, to respect other's rights and create values in relation to all of these. Parents are the first lecturers on the subject of sexuality (Corbett,1991). 
In relation to this, the sexual development during puberty presents the most critical stage in life. Puberty starts with the secretion of sex hormones, and becomes more pronounced after girls have their first period, and boys having their first ejaculation. The appeareance of this shows that the individual has developed the necessities for reproduction. It is also a distinctive in both mental and behavioral aspects of the individual. It will make it a lot easier on an individual that goes through puberty to know the changes in the body and the function of the genitals in order to better understand this phase in life. With the fluctuating hormonal balances comes a change in the sexual instincts. For children protect themselves from sexual abuse can only be archived by sexual education. Sexual abuse is the case when a minor is forced by an adult to prositution, or to sexual acts such as being touched in genital areas, and being used by the abusers in order to sexually stimulate themselves. Research shows that individuals who are subject to such abuse are mostly abused by those who are closest to them. For a family member to watch a child naked, wanting to see their genitals, or showing their own genitals to a child, or performing sexually stimulating acts on their own and the victims genitals are some of the most common cases(Gölbaşı, 2002).

Mentally deficient individuals are commonly abused. The fact that they lack awareness of the possible abuse whenever they are relating to the person before them makes them victims in the fullest sense of the word. Whether it occurs in secret or through open suggestions drives the children into dispair, plagued by a flurry of emotions such as fear, shame or uneasiness, not knowing what to do. The relation that advances slowly and stepwise as hugging, touching and kissing, the child can only recognize this as affection. At first, the cildren may only perceive this as love and fun. But as it progresses, the child will eventually lose trust with a sudden change in things (Öztop, 2010).

In this regard, the sexual development in mentally deficient children follows the same course as normal children, however slower less progressive in relation to their mental deficiency. When considering the sexual development of a mentally deficient individual, one should take into account their individual mental development, rather than the norms for a person of their chronologic age. If this is taken as the basis, it is possible to understand what a child needs in throughout their sexual development process. It is said that mentally deficient individuals exhibit intense sexual behavior, though this only appears to be the case because the individuals in question often do not know when or where to exhibit such behavior. If evaluated in such a manner, instances that normally would seem to be problematic, are in fact, not so (Artan, 2005). The study is all about the families having ongoing unfulfilled needs in regards to education programmes on this subject. Most parents in North Cyprus are ignorant and do not know what to do, due to a lack of a proper family programme for parents with mentally challenged children. If one were to look abroad, one would see that the sexual education programmes for normally developed individuals are most often taught by women, and often concern themselves with general information regarding genitals, safe-sex, STD's, and behavioral differences (Sungur, 1998).

In addition to this, there exist certain special programmes prepared and sponsored by the Turkish ministry of Education that aim to provide proper pre-school, elementary and highschool education children on par with their current sexual development for them to get the right idea about the process. Again, in certain areas in Turkey, we see that families with both normal and mentally deficient children are informed by the Counselling Research Department on subject such as process of sexual negligence and abuse and how families should react to this, however sexual education is more prevalent for parents with normal children attending in private schools and pres-chools either daily as yearly part of the overall curriculum. This process has shown that we can accomodate such needs only through the information that we can procure from the parents of such children, so the purpose of the first stage would be to learn about the general views of parents of children with mild mental deficiencies. 


\section{Methodology}

In order to gather proper and sufficient data for this study, a qualitative approach in the form interviews was taken, and a semi-structured interviewing technique was used. Qualitative research is defined as "A type of research, where data is gathered through ways such as observation, interviews and document analysis, where notions and events are laid down progressively in real and whole environments." (Yıldırım and Şimşek, 2006).

\subsection{Participants of the Research}

As on par with the aims of this study, the participants have been selected via typical case sampling, a purposive sampling method. The reason for this is that it allows for a thorough study of instances with a lot of information (Yıldırım ve Şimşek, 2006). In accordace with this, the participants have been selected from parents whose children are currently attending a School for children with mental deficiencies and special needs in North Cyprus. The participants were made up from a total of 20 parents (16 mothers, 4 fathers) who have volunteered for the the interview.

Table 1. Characteristics of Participants

\begin{tabular}{|l|l|l|l|l|l|}
\hline Participant & Sex & Age & Profession & $\begin{array}{l}\text { Age of the } \\
\text { child }\end{array}$ & $\begin{array}{l}\text { Sex of the } \\
\text { child }\end{array}$ \\
\hline 1 & F & 35 & Civil servant & 15 & M \\
\hline 2 & F & 54 & Housewife & 17 & F \\
\hline 3 & F & 49 & Housewife & 14 & M \\
\hline 4 & F & 49 & Housewife & 14 & M \\
\hline 5 & F & 48 & Civil servant & 17 & F \\
\hline 6 & M & 53 & Civil servant & 15 & M \\
\hline 7 & F & 43 & Housewife & 14 & M \\
\hline 8 & M & 45 & Civil servant & 15 & M \\
\hline 9 & F & 50 & $\begin{array}{l}\text { Kindergarten } \\
\text { Teacher }\end{array}$ & 14 & F \\
\hline 10 & F & 31 & Housewife & 14 & M \\
\hline 11 & F & 50 & $\begin{array}{l}\text { Kindergarten } \\
\text { Teacher }\end{array}$ & 14 & M \\
\hline 12 & F & 35 & $\begin{array}{l}\text { Kindergarten } \\
\text { Teacher }\end{array}$ & 13 & F \\
\hline 13 & F & 40 & $\begin{array}{l}\text { Kindergarten } \\
\text { Teacher }\end{array}$ & 13 & F \\
\hline 14 & F & 38 & Housewife & 17 & F \\
\hline 15 & F & 40 & Housewife & 13 & F \\
\hline 16 & M & 46 & Civil servant & 16 & M \\
\hline 17 & F & 34 & Housewife & 14 & F \\
\hline 18 & M & 52 & Civil servant & 17 & M \\
\hline 19 & F & 42 & Housewife & 13 & M \\
\hline 20 & F & 49 & Housewife & 15 & M \\
\hline
\end{tabular}

\subsection{Data Collection Process}

The semi-structured interview method was used for the study. A questionnaire of semi-structured questions was prepared for the interview. The open-ended interview questions have been selected from a question pool of a total number of 45 questions. These questions have then been examined by three experts on whether they were relevant and understandable. The 
data has been finally gathered in the months of October and February 2013. The interview questions used in the questionnaire are given at the end of this research.

After the interview questions have been determined, interviews have been conducted with the 20 volunteering parents. The parents have been informed on the purpose of the study prior to the interview. They also were informed that is was crucial that they presented views and suggestions clearly and without holding back anything. The researchers have also informed the parents that they will use a voice recorder, that will allow for a more fluid and thorough interview, while allowing for a more detailed evaluation of the results. In addition to this, it was explained to the parents that the recordings would only be made available to the researchers, and no one else. The parents were not shown the questions prior to the interview, and had no knowledge of the contents of the questions. The interviewers did their best to keep parents on track whenever they spoke of things irrelevant to the subject, and informed them that they could re-read the questions in the case that they didn't understand.

Interview questions were asked to parents in pre-determined order. If parents were unclear or cannot give exactly an answer to the corresponding interview question, the corresponding question were asked more clear and understandable once again and after that parents were asked if they need to add any other comments on corresponding topic. If the researchers received an answer for a single question that also answered another question, these were not asked again. The interview was done anonymously, though parents were told that they could use their names if they wanted to. These were explained throughout the interview whenever they were necessary and without re-directing the subject.

\subsection{Validity and Reliability of the Research}

Experts were asked for their opinion on the interview questions, research data and comments in order to maintain the internal validity of the study. In addition to this, $30 \%$ the participants have been shown the resulting conclusions and comments after the analysis of the data for confirmation from the participants themselves.

The external validity, i.e. transferability of this research was maintained by presenting examples via directly quoting the comments of the parents. A consistancy survey was conducted by an expert in order to maintain the internal reliability of the study, and it was determined that the corrolation between the analytical approaches taken and conclusions that were reached were indeed consistent.

In order to maintain external reliability, the conclusions, comments and the raw data that was used to reach them were all subject to examination by experts for approaval.

\subsection{Analysis of Data}

The descriptive analysis approach, which is used as an analysis of qualitative research data was used as a method of analysis of the collected data. In this approach, the collceted data is interpreted and summarized according to pre-determined themes.

In the descriptive analysis, direct quotations are often used in order to reflect the interviewed or observed individual's views. The purpose of this analysis is to describe the findings in an organized and interpreted way. After that, the subsequent descriptions are explained and interpreted, cause-effect relationships are examined and reached to some conclusions. Correlation of the emerging themes, meanings and the further estimations, can take place between the dimensions of the interpretations (Yıldırım ve Şimşek, 2006).

Reserachers have moved the stage of breakdown of the records after concluding the interviews. In the stage of breakdown of the records, each parent in a spearate interview form was used. The 
voice records created during the interviews were transferred without any modifications or changes for each parent. The $\% 50$ of these records were matched with the voice records by the field expert for accuracy. Demographic information obtained from the parents and information related with research questions created as tables. An analysis form is created in order to create a comprehensive state of demographic information and corresponding tables. Information was transferred to these analysis forms. The data gathered during the analysis stage, were used as a comparions in the creation of findings. The findings of the study were revealed during the stage of determination of questions in direction of identified themes.

\section{Findings}

The findings of the interview were presented in this section. Each and every interview question's finding is given below. 'P' stands for "Participant".

Q1-Is he/she aware of his/her own sex? Can he/she determine the sex of an opposing person when asked? If yes, which ones?

The response for this question was positive for all the 20 participants regarding the self-awareness about their own sex and the awareness of the sex of others.

Q2-Is he/she asking questions about sex organs? If yes, which ones?

18 out of the 20 parents have reported that their child does not ask any questions about his or her own reproductive organs, while two have said that their child had inquired about them on certain occasions. (p-10) would simply ignore the question while (p-1) would additionally respond to the child with "you shouldn't ask about such things", whereas both would sometimes react by changing the subject.

Q3-When seen someone bathe, and wanting to watch, what type of questions does he/she ask about the person bathing?

18 of the inquired children would did not have such needs or requests, while two parents (p-11) and (p-12) have reported that their children are highly inclined to go in and watch as someone is bathing, exclaiming that "he/she has something else that I want to see, don't close the door, I want to see", upon which they would be warned by their parents and asked to leave the bathroom.

Q4-Does he/she take up roles such as father/mother when playing a household game? If yes, elaborate.

20 out of the 20 parents have reported that their children play video games on the computer only, and do not participate in role plays.

Q5-Does he/she speak about sexuality with friends? If yes, elaborate.

17 out of the 20 parents have told that their children do not speak about sexuality with their friends, only three students (whom currently reside in a Kindergarten in Northern Cyprus) have been observed to do this amongst themselves especially while watching TV, and upon being asked by their mothers or aunts, they would give no answers.

Q6- Does he/she wishes to be alone while dressing(is he/she aware of his/her private space)?

10 out of the 20 children (p-1), (p-2), (p-5),(p-7), (p-9), (p-11), (p-12), (p-14), (p-17), (p-19) have been reported by their parents as being unaware of their privacy, that they are able to dress or undress regardless of place or people around them, or do show the tendency to enter other peoples rooms without asking for permission, in the case of (p-11), which shows that they are not aware of either their own or other people's privacy.

Q7- Does he/she experience shame, upon hearing a sexually explicit jokes or words, or does he/she repeat the joke or words in question? What do you do in the case of the latter? 17 out of 20 parents have stated that their child does not repeat any sexually explicit jokes or words, while three (p-1), (p-16), (p-10) were reported to repeat obscene words upon hearing 
them. When inquired about their reaction, parents have told that they reprimand their children upon uttering obscenity, although that this didn't stop their children from doing so again.

Q8-Does he/she imitate a person of the opposite sex as part of a role play? If so, how?

20 out of the 20 parents have reported that regardless of gender, none of their children have imitated the opposite sex.

Q9- Does he/she try to kiss strangers? If so, how do you react to it?

Two out of the 20 parents (p-12), (p-9) have reported that their children were inclined to kiss strangers, and that they would warn their children when they exhibited this behavior, by saying "We don't know this person" or "what are you doing, you should not interact with people that we don't know.".

Q10-Does he/she allow strangers to kiss him/herself? If so, how do you react to it? 13 out of 20 parents (p-1), (p-2), (p-3), (p-4), (p-5), (p-7), (p-8), (p-9), (p-11), (p-14), (p-16), (p-17), (p-19) have reported that their children do not say no to people that say "come here, let me kiss you", and two parents (p-12), (p-13) have reported that they allowed such behavior because they liked it, whereas five (p-6), (p-10), (p-15), (p-18), (p-20) have stated that their children did not allow this.

Q11- Does he/she try to hug strangers? If so, how do you react to it?

Two out of the 20 parents (p-12), (p-13) have reported that their children were inclined to kiss strangers, and that they would warn their children when they exhibited this behavior, by saying "We don't know this person.

Q12- Does he/she allow strangers to hug him/herself? If so, how do you react to it? 13 out of 20 parents (p-1), (p-2), (p-3), (p-4), (p-5), (p-7), (p-8), (p-9), (p-11), (p-14), (p-16), (p-17), (p-19), have reported that their children do not say no to people that say "come here, let me hug you", and two parents (p-12), (p-13) have reported that they allowed such behavior because their kids liked it, whereas five (p-6), (p-10), (p-15), (p-18), (p-20) have stated that their children did not allow this.

Q13- When faced with a situation that he/she disapproves of, does he/she know to say "no"?

17 out of the 20 parents have stated that their children may not always know when or how to say no, whereas three (p-15), (p-10), (p-20) have stated that their children are able to definately say no to something they don't approve of.

Q14-Does he/she tell you about his/her frightful, hurtful or sad experiences? If he/she does not and you do find out, what is your reaction?

10 out of 20 parents (p-1), (p-2), (p-3), (p-4), (p-5), (p-8), (p-9), (p-11), (p-14), (p-15), have reported that their children usually tell their parents about whatever might have happened to them, though incomplete, whereas the other parents stated that they inquire about their children from other parents, teachers and the school principal if they suspect that something might have happened.

Q15- Is he/she aware which of the people around him/her can be trusted or not?

Only two our of 20 parents (p-10) (p-15) responded by saying that their children are aware who they can trust or not, whereas the rest have stated that they are highly open to suggestion regardless with whom they are interacting.

Q16-Does he/she ever tell you about it after being reprimanded for exhibiting inappropriate behavior(if not, to whom? What is your reaction?)?

10 out of 20 parents(p-1), (p-2), (p-3), (p-4), (p-5), (p-8), (p-9), (p-11), (p-14), (p-15), have stated that their children tell them about the reactions they get from other people, where as the rest have state that they can or can't understand such a case from the way their children act and added that they inquire about it by contacting the school or parents of other children. 
Q17- Is he/she aware that that he/she shouldn't be watching a person while undressing? What do you do in such a situation?

10 out of the 20 parents have reported that their children are careful about the privacy of others, though in very exceptional circumstances, they sometimes try to watch other people while undressing, though upon being discovered, they quickly reverted their behavior. The rest of the parents $(\mathrm{p}-1),(\mathrm{p}-2),(\mathrm{p}-5),(\mathrm{p}-7),(\mathrm{p}-9),(\mathrm{p}-11),(\mathrm{p}-12),(\mathrm{p}-14),(\mathrm{p}-17),(\mathrm{p}-19)$ have given answers such as "my child enters the room while I'm dressing/undressing" (p-1), "enters the bathroom while I'm inside" (p-14), "enters any room, including mine without knocking and watches" (p-12), "enters the rooms of his sisters or the bathroom without knocking" (p-11). Upon being asked about their response, three of the parents (p-5), (p-7), (p-19) answered that they do not warn their children and allow them to watch, while 7 parents stated that they responded by a warning or telling them to get out, or to knock the door.

Q18- Does he/she enjoy playing with a person of the same sex, or the opposite sex?

10 out of the 20 parents have reported that their children do not enjoy playing at all, while 5 (p-6), (p-7), (p-8), (p-10), (p-16) have reported that their child only plays video games on the computer, while the rest (p-2), (p-3), (p-4), (p-13), (p-14) have reported that their children play with anyone regardless of sex.

Q19- Does he/she picks his/her own clothing? And if so, is he/she able to differentiate between gender-specific clothing?

18 out the 20 parents have stated that their children are able to pick their own clothing, while the parents (p-1) and (p-2) have stated that their children do not feel the need to do so as their parents already pick clothes for them.

Q20-Is he/she able to pick an appropriate toy for her gender? If not, what is your response?

In response to this question, 10 parents have reported that their child does not enjoy playing at all, while 5 reported that their children play video games on the computer that they picked themselves, while the rest reported that they did not have any special preferences regarding toys or games.

Q21-When asked a question of sexual nature, what kind of answers do you give?

13 out of 20 parents (p-1), (p-5), (p-6), (p-7), (p-9), (p-10), (p-11), (p-14), (p-16), (p-17), (p-18), (p-19), (p-20) have reported that they have not received any questions regarding sexuality because of they ignored or reprimanded previously asked questions by answering "Don't ask such things" (p-1), whereas five parents (p-3), (p-4), (p-2), (p-8), (p-15), stated that their children have asked no questions whatsoever about the subject, whereas two parents (p-12) and (p-13) have said that their children frequently ask them about sexuality, though they would receive no answers.

Q22-How do you answer questions regarding his/her own gender?

Two parents (p-12) and (p-13) have said that their children ask them about their gender, though the parents would not answer them, whereas the rest have stated that they received no questions from their children whatsoever regarding the subject.

Q23-Do you ever leave your child alone with strangers? If so, under which circumstances?

20 out of the 20 parents stated that they do not leave their children alone with strangers due to the fear that something might happen to them.

Q24- Do you touch the private parts of your child as part of a joke?

20 out of 20 parents gave "no" as an answer.

Q25-Do you allow your child to be touched, kissed or hugged by strangers?

20 out of 20 parents have stated that they do not allow their children to interact with strangers, whether kissing, hugging or touching. However they also said that they concerned because they are unable to interfere with this in places such as school, or during a trip, or while being other family members. 


\section{Discussion \& Conclusion}

In accordance with the information gained from the families, it was found out that children are in need of support in the sexual education and development process. One important finding was the establishment that the inappropriate behavior shown by children was tied to manifestation of the changes in hormonal balances that is exhibited during puberty.

The main factor in determining needs throughout this process is for children to know their own and other people's sex, as a sort of a precondition. Parents usually tend to ignore the questions of the children regarding their own or other peoples genitals as to know the differences between the sexes, as they do not know how to answer, and either don't answer these questions by changing the subject, or claiming that such questions are "obscene".

If we do a literature review, we can see that the age for such questions is $25-72$ months after birth for normally developing individuals. The fact that children do not receive satisfactory answers regarding these questions renders them unable to learn the necessary steps to exhibit the proper behavior, as we can see some children that are yet inclined to watch a person while bathing, as there are some who ask questions relating to the subject (in inappropriate places or to the wrong people). This shows that these problems turn into behavioral patterns because the children have not been properly informed about the aforementioned subjects.

We can see that most of the children do not know about the concept of privacy, when we look at how some children simply don't know that they should not barge into a room when someone is dressing or undressing regardless of the person that is inside, or that they are comfortable with dressing or undressing regardless of the surround people or environment.

Although some families warn their children, the fact that they themselves do not show the same courtesy by entering the room while their children are dressing or undressing does not allow them to establish a concept of privacy, and since we can see from the literature that sexual abuse of children is usually done by people that are close associates, the dressing or undressing of such children that lack a concept of privacy in front of total strangers usually exhibit the first signs of sexual abuse.

According to the interviews that were conducted with family members, one can see that there is an immidate need for a change of both the house environments, and behavioral patterns of children that previously were not considered as a risk by the parents.

When their disposition towards kissing, hugging or touching strangers is considered, we can see that some parents admit that their children are inclined to accept such behavior from strangers, even when warned not to do so. This would result in the children accepting this type of behavior as normal in the future and further advances made on their person would not be met with any type of response or resistance, which would make sexual abuse a lot easier. Because of this, parents are often worried and disinclined to leave their children alone, hindering our strong emphasis on "the acquisition of independent living skills" in special education. If we examine the susceptibility of children to sexual abuse, we can see that children often submit silently to any sexual abuse that they encounter as they lack the necessary judgement and assessment skills that allow them to recognize this as anything but as a form of affection or attention.

Many researchers have stated in their studies that individuals with mental deficiencies are not given enough information regarding sexuality. It is known that normal children have greater chances of receiving information regarding this subject from their parents or from the media.

However, it is a lot harder for mentally deficient individuals to have access to information regarding sexuality, as mentally deficient individuals are mostly in special education programmes and have difficulties discussing this with friends when they have difficulties relating with them, with their parents being mum, and the media overly complex for them to extract this kind of information, we can see that it is necessary that sexual education must come in the form of a special education programme. This is especially important since the sexual 
abuse of minors yet continues to prevail as a problem inside every society and socioeconomic class (Çatık ve Çam, 2006).

According to a study, mentally deficient children are more susceptible to abuse than normal children, and amongst children with disabilities, mentally deficient children are more commonly subjected to sexual, physical and emotional than other children with disabilities(Bilge ve Baykal, 2010). Ludny and Kilpatrick (2006) state that the educational needs of mentally deficient children are not met, even though explicitely stated in the convention for the protection of Human rights, and even worse, are most commonly the victims of sexual abuse by their legal guardians as studies show (Landsdown, 1998).

It has been established that mentally deficient children are more susceptible to abuse outside of their home environments, because they mostly reside in boarding schools, and are dependent on others for support, with their limited skills in communication barring them from understanding any behavior of ill purpose(Paul and Cawson, 2002), and the fact that they receive either insufficient or no sexual education(Cooke and Standen, 2002) at all leaves them more vulnerable to being abused.

In response to these conclusions or for future studies, the following terms may be suggested; a) A sexual education programme should be developed to be put in use by the families immidiately, b) That the list of needs be refurbished in accordance with the behavioral changes in children and the information given to the families, in order to further the studies done on the behavior that needs be conferred upon the children, c)That education is also given to the staff and the teachers at school, with special emphasis on abuse and any legal repercussions in the case on abuse, should be considered for future studies.

\section{Acknowledgement}

The authors would like to thank to Assoc. Prof. Dr. Oğuz Serin and Asst. Prof. Dr. Arif Sari for their analytical contribution and support.

\section{References}

Akçamete, G., (1997). Türkiye'de Özel Eğitim, Anadolu Üniversitesi Özel Eğitim Dergisi, Ankara.

Artan, İ., (2005) “Engelli Çocuk ve Gençlerin Cinsel Eğitimi”, Bilim ve Aklın Aydınlığında Eğitim Dergisi, Issue:39.

Bilge, A., Baykal, Z., 2010. ' 'Zihinsel Engelli Birey ve Cinsellik' www.ozida.gov. tr,

Corbett, J., (1991) So, who wants to be normal?, Disability, Handicap \& Society, 6, pp. 259-260.

Cooke P., Standen PJ., (2002). Abuse and Disabled Children Hidden needs? Child Abuse Review, 11.

Çatık, A., Çam, O., (2006). 'Hemsire ve Ebeveynlerin Çocuk İstismarı ve İhmalinin Belirti ve Risklerinin Tanıma Düzeylerinini Saptanması' Eğe Üniversitesi Hemşirelik Yüksek Okulu Dergisi.

Eripek, S. (2005) 'Özel Eğitim'; Anadolu Üniversitesi wep-ofset Tesisleri, 2. Edition ISBN:975-06-0149-1. 
Gölbaşı, Z., (2002). Hasta Cinselliğinin Değerlendirilmesi ve Hemşirelik Engeller ve Öneriler, Anadolu Hemşirelik ve Sağlık Birimleri Dergisi.

Landsdown, G. (1998). Practice and implementation: The rights of disabled children. The International Journal of Children's Rights, 6, 221-227.

McCobe. Mp., (1999) Sexual Knowledge, 'Experience and Feelings Among People With Disability', Kluwer Academic Puplishers 1573-6717.

Özcan, Ö.Ö., (2010). Cinsel İstismar Vakalarının Sosyodemografik ve Klinik Özelliklerinin Değerlendirilmesi. Volume 48, issue 4, pp. 44-53.

Sungur, M. Z.(1998). Cinsel Eğitim. Ankara Üniversitesi Psikiyatri Dergisi; S. 103-108

T.C. (2011) Aile ve Sosyal Poletikalar Bakanlığı Özürlü ve Yaşlı Hizmetleri Genel Müdürlü'ğü Yayınlanmış Karaname. Ankara.

Yıldırım, A. ve Şimşek, H. (2006). Sosyal Bilimlerde Nitel Araştırma Yöntemleri, Ankara; Seçkin Yayınevi.

Yıldırım, A. ve Şimşek, H. (2005). Sosyal Bilimlerde Nitel Araştırma Yöntemleri, Ankara; Seçkin Yayınevi. 


\section{Appendix}

Appendix 1. Survey Questionnaire used in Interview

1-Is he/she aware of his/her own sex? Can he/she determine the sex of an opposing person when asked? If yes, which ones?

2-Is he/she asking questions about sex organs? If yes, which ones?

3-When seen someone bathe, and wanting to watch, what type of questions does he/she ask about the person bathing?

4-Does he/she take up roles such as father/mother when playing a household game? If yes, elaborate.

5-Does he/she speak about sexuality with friends? If yes, elaborate.

6-Does he/she wishes to be alone while dressing(is he/she aware of his/her private space)?

7-Does he/she experience shame, upon hearing a sexually explicit jokes or words, or does he/she repeat the joke or words in question? What do you do in the case of the latter?

8-Does he/she imitate a person of the opposite sex as part of a role play? If so, how?

9-Does he/she try to kiss strangers? If so, how do you react to it?

10-Does he/she allow strangers to kiss him/herself? If so, how do you react to it?

11-Does he/she try to hug strangers? If so, how do you react to it?

12-Does he/she allow strangers to hug him/herself? If so, how do you react to it?

13-When faced with a situation that he/she disapproves of, does he/she know to say "no"?

14-Does he/she tell you about his/her frightful, hurtful or sad experiences? If he/she does not and you do find out, what is your reaction?

15- Is he/she aware which of the people around him/her can be trusted or not?

16-Does he/she ever tell you about it after being reprimanded for exhibiting inappropriate behavior(if not, to whom? What is your reaction?)?

17- Is he/she aware that that he/she shouldn't be watching a person while undressing? What do you do in such a situation?

18- Does he/she enjoy playing with a person of the same sex, or the opposite sex?

19- Does he/she picks his/her own clothing? And if so, is he/she able to differentiate between gender-specific clothing?

20-Is he/she able to pick an appropriate toy for her gender? If not, what is your response?

21-When asked a question of sexual nature, what kind of answers do you give?

22-How do you answer questions regarding his/her own gender?

23-Do you ever leave your child alone with strangers? If so, under which circumstances?

24-Do you touch the private parts of your child as part of a joke?

25-Do you allow your child to be touched, kissed or hugged by strangers?

\section{Copyright Disclaimer}

Copyright for this article is retained by the author(s), with first publication rights granted to the journal. This is an open-access article distributed under the terms and conditions of the Creative Commons Attribution license (http://creativecommons.org/licenses/by/3.0/). 